\title{
Ways of applying zinc to maize plants growing in Oxisol: effects on the soil, on plant nutrition and on yield
}

\author{
Formas de aplicación de zinc para las plantas de maíz que crecen en Oxisol: \\ efectos sobre el suelo, la nutrición de las plantas y la productividad
}

\author{
Aline Peregrina Puga ${ }^{* 1}$, Renato de Mello Prado 2 , Ivana Machado Fonseca ${ }^{3}$, \\ Diego Wyllyam do Vale ${ }^{4}$ Cíntia Carla Avalhães ${ }^{5}$
}

\begin{abstract}
SUMMARY
The way of applying zinc can influence the zinc uptake and productivity of crops, especially cereals that have high demand for this nutrient. The aim of this study is to evaluate methods of $\mathrm{Zn}$ application on soil, nutritional status and productivity of maize. For this, an experiment was undertaken at FCAV/UNESP, Jaboticabal-SP, in Oxisol clay (DTPA on Zn: $0.5 \mathrm{mg} \mathrm{dm}^{-3}$ ) with maize (hybrid Simple Impact), from December through May 2009. Nine treatments with three doses of $\mathrm{Zn}$ in soil banded application (in furrows) and three doses of $\mathrm{Zn}$ by incorporation in soil (0-20 cm depth), foliar application, seed application and control (no $\mathrm{Zn}$ ). The treatments were arranged in a randomized block design with four replications. Regardless of the method, $\mathrm{Zn}$ application promoted higher contents of this micronutrient in soil and higher accumulation in the shoots as well as increasing $\mathrm{Zn}$ in the maize grain. However, it did not affect the nutritional status and yield of the maize. The $\mathrm{Zn}$ application in the soil resulted in a greater $\mathrm{Zn}$ uptake by plants and maize yield, compared to $\mathrm{Zn}$ application in the plant by seed or foliar.
\end{abstract}

Key word: Zn, Zea mays L., micronutrient, application methods.

\section{RESUMEN}

La manera de aplicar zinc puede influir en la absorción de zinc y productividad de los cultivos, especialmente los cereales que tienen alta demanda de este nutriente. El objetivo de este estudio es evaluar los métodos de aplicación de Zn en el suelo, el estado nutricional y el rendimiento de maíz. Para ello, se realizó un experimento en FCAV/UNESP, Jaboticabal en Oxisol arcilloso (ZnDTPA: 0,5 mg dm-3), el maíz (híbrido de impacto simple) de diciembre a mayo de 2009. Se aplicaron nueve tratamientos con tres dosis de Zn en forma localizada (en las crestas) y tres dosis de Zn mediante la incorporación en el suelo (0-20 cm), foliar, las semillas y el control de la aplicación ( $\sin \mathrm{Zn}$ ). Los tratamientos se dispusieron en un diseño de bloques al azar con cuatro repeticiones. Independientemente del método, la aplicación de Zn promovió mayores niveles de zinc mayor acumulación en el suelo y en el aire, así como aumento de Zn en el grano. Sin embargo, no afectó el estado nutricional y el rendimiento de maíz. La aplicación de Zn resultó en un incremento de la absorción de zinc por las plantas y el rendimiento de maíz en comparación con la aplicación de Zn a la semilla de la planta o forma de hoja.

Palabra clave: Zn, Zea mays L., micronutrientes, los métodos de aplicación.

\section{Introduction}

Tropical soils, in general, present low zinc (Zn) concentration (Lopes, 1983), be it with the original material or by planting practices with the use of intensive crops without necessary fertilization. In literature many causes of $\mathrm{Zn}$ deficiency is presented in crops as: low levels of $\mathrm{Zn}$ in the soil, excessive lime, low levels of organic matter and temperature, high levels of $\mathrm{P}$ in the soil or in the fertilizer, excessive applications of $\mathrm{N}$ and restriction of root development (Lucas and Knezek, 1972).

Among the micronutrients, the importance of this element in the crops in Brazilian soils is

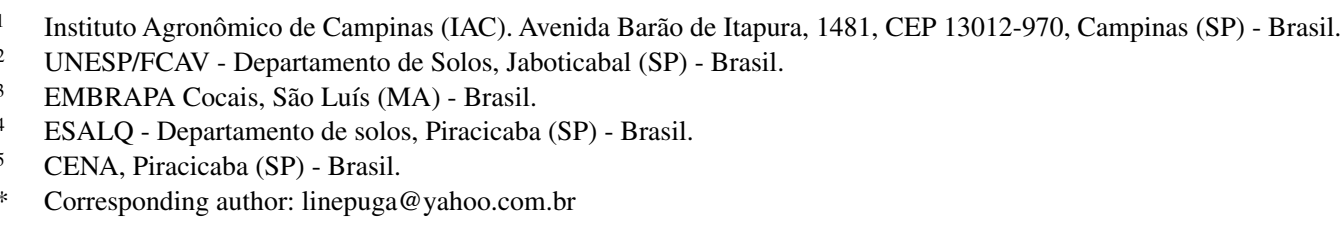

Fecha de Recepción: 15 Noviembre, 2010.

Fecha de Aceptación: 8 Agosto, 2011. 
unquestionable for its frequent deficiency, mainly in soils that are not from basic rocks (Abreu et al., 2001). According to Galrão (1994) Zn is one of the micronutrients whose deficiency has limited crop production in Brazil.

This way, the Zn deficiency is recognized as a worldwide nutritional problem in the crop production (Fageria, 2001), especially, as poaceae which are demanded in this nutrient. According to Malavolta (1980) for obtaining high yield in maize it is indispensable the supply of micronutrients, mainly boron and $\mathrm{Zn}$.

The $\mathrm{Zn}$ activity is effective for determined relevant process in the physiological and nutritional homeostasis of the plant, acting as an activator or enzyme component, it participates of the photosynthesis in the $\mathrm{C} 4$ plants, it is necessary for the production of tryptophan and for the maintenance of the biomembrane integrity (Malavolta, 2006) and still participate in the protein metabolism (Bowen, 1979) and acting as structural component of the ribosomes (Marschner, 1995). With Zn deficiency, the plant may present symptoms of strong chlorosis along the main nervure and purple shades on the leaves, shortening of the internodes and decrease of the leaf production, besides the reduction of growth and production (Malavolta, 1980).

$\mathrm{Zn}$ is a micronutrient which enhances the grain productivity in the maize production (Melarato, 2000) and for the soils in the São Paulo state the recommended doses are of 2 to $4 \mathrm{~kg} \mathrm{ha}^{-1}$, according to the element content of the soil (Raij and Cantarella, 1997). However, according to Fageria et al. (2002), the quantity of fertilizer to be applied to correct the $\mathrm{Zn}$ deficiency in the crops depend on the content of this micronutrient in the soil, climate conditions and vegetal specie.

The supply of $\mathrm{Zn}$ in the crops can be done directly on the soil, as fertilizers, via foliar fertilization or seed treatments (Gonçalves Júnior et al., 2007). In concordance to Galrão (1996), for maize applications on leaves or seeds are rarely recommended due to lack of research data. Consequently, complete researches involving all the forms of $\mathrm{Zn}$ application are necessary and the study of the effects in the soilplant systems, and its effects in the grain quality and productivity.

Therefore, the aim of this study is to evaluate the methods of applying $\mathrm{Zn}$ on the soil, the nutritional state and the productivity of the maize crop.

\section{Material and Methods}

The experiment was done at the farm school belonging to FCAV/UNESP, Jaboticabal campus in São Paulo state, at $21^{\circ} 15^{\prime} 22^{\prime \prime} \mathrm{S}$ to $48^{\circ} 18^{\prime} 58^{\prime}$ 'W and the altitude of $575 \mathrm{~m}$, in an Oxisol dystrophic classified by EMBRAPA (2006), clay texture. The soil chemical analyses (0-20 cm soil layer) the method used was written by Raij et al. (2001), having the following properties: $\mathrm{pH}$ in $\mathrm{CaCl}_{2}=4.3$; O.M. $=21 \mathrm{~g} \mathrm{dm}^{-3} ; \mathrm{P}($ resin $)=19 \mathrm{mg} \mathrm{dm}^{-3}$; $\mathrm{K}=1.5 \mathrm{mmol}_{\mathrm{c}} \mathrm{dm}^{-3} ; \mathrm{Ca}=7 \mathrm{mmol}_{\mathrm{c}} \mathrm{dm}^{-3}$; $\mathrm{Mg}=4 \mathrm{mmol}_{\mathrm{c}} \mathrm{dm}^{-3} ; \mathrm{H}+\mathrm{Al}=42 \mathrm{mmol}_{\mathrm{c}} \mathrm{dm}^{-3} ;$ base $\operatorname{sum}(\mathrm{SB})=12.5 \mathrm{mmol}_{\mathrm{c}} \mathrm{dm}^{-3} ; \mathrm{CEC}=54.5 \mathrm{mmol}_{\mathrm{c}} \mathrm{dm}^{-3}$ $\mathrm{e} \mathrm{V} \%=23 ; \mathrm{B}=0.18 \mathrm{mg} \mathrm{dm}^{-3}, \mathrm{Cu}=0.8 \mathrm{mg} \mathrm{dm}^{-3}$, $\mathrm{Fe}=19.0 \mathrm{mg} \mathrm{dm}^{-3}, \mathrm{Mn}=16.1 \mathrm{mg} \mathrm{dm}^{-3}$ and $\mathrm{Zn}=0.5 \mathrm{mg} \mathrm{dm}^{-3}$.

The plots were composed by four rows, $5 \mathrm{~m}$ long, the two middle rows are considered useful and the others are margins, with a spacing between rows of $0,9 \mathrm{~m}$. The simple hybrid maize, Impacto, was used. The average rain in the experimental period was of $996 \mathrm{~mm}$.

The following nine treatments were applied: three doses of $\mathrm{Zn}(2,4$ and $8 \mathrm{~kg}$ of $\mathrm{Zn}$ per ha) applied locally (in furrows); three doses of $\mathrm{Zn} \mathrm{(6,12} \mathrm{and} 24$ $\mathrm{kg}$ of $\mathrm{Zn}$ per ha) applied by incorporation (layers of 0-20 cm deep); foliar application (0.4 kg of $\mathrm{Zn}$ per ha); seed application (40g of $\mathrm{Zn} \mathrm{kg}^{-1}$ of seeds) and control (no $\mathrm{Zn}$ application). The treatments with micronutrient via soil and foliar, received $\mathrm{Zn}$ in the form of $\mathrm{Zn}$ sulfate ( $79 \% \mathrm{Zn}$ ), and, via seeds in the form of $\mathrm{Zn}$ oxide $(22.7 \% \mathrm{Zn})$. The treatments were arranged in a randomized block design with four replications.

To evaluate the nutritional state, leaf samples were collected, one third of the center of the leaf is removed from the base of the maize ear, when the crop is in flower, according to Cantarella et. al (1997). During harvest, the maize plants were separated in leaves, stems, ear husks, cobs and grains. The preparation of the samples were realized (washing and drying), determining the dry matter and the $\mathrm{Zn}$ content, and, calculating the accumulation of this nutrient on the shoot. In each plot, were determined: the number of grains per maize ear, 1.000 grain mass and grain productivity (13\% moisture base).

Soil sampling was done after harvest $(0-20 \mathrm{~cm}$ layer) in the fertilizing area. The $\mathrm{Zn}$ content was determined by extractors DTPA (Raij et al., 2001) and Mehlich-1 (Nelson; Mehlich, 1953). 
The data from the studied variable were subjected to variance analysis by the F-test and using the degrees of freedom from treatments and orthogonal contrasts. Moreover, a polynomial regression was performed for doses pertaining to the $\mathrm{Zn}$ application methods via soil.

\section{Results and Discussion}

\section{Effects of the treatments in the chemical attributes of the soil}

In all the comparisons there were no differences in the chemical attributes of the evaluated soils, except for the Zn content, as expected (Table 1).

For the $\mathrm{Zn}$ content, it can be verified by the first comparison group tested (control vs. other treatments) is that the $\mathrm{Zn}$ application independently of the manner, it provoked a higher content of this nutrient, for the extractor DTPA as for Mehlich-1, in the soil of maize crop, corroborating Galrão (1994) in the study of Zn application methods in soil, where the control presented a minor content of this micronutrient $\left(0.3 \mathrm{mg} \mathrm{dm}^{-3}\right)$. However, Galrão (1996) in similar study of $\mathrm{Zn}$ in maize, observed differences only in some treatment doses in which $\mathrm{Zn}$ was applied by incorporating it in the soil, the dose being of $7.2 \mathrm{~kg} \mathrm{ha}^{-1}$ provided a higher content of this micronutrient in soil $\left(1.6 \mathrm{mg} \mathrm{kg}^{-1}\right)$, however this effect was expected due to the high $\mathrm{Zn}$ doses in soil $\left(2\right.$ to $\left.24 \mathrm{~kg} \mathrm{ha}^{-1}\right)$ compared to the application on the plant (up to $0.4 \mathrm{~kg} \mathrm{ha}^{-1}$ ). Jamami et al. (2006), maize field study, verified that the dose of $2 \mathrm{~kg} \mathrm{ha}^{-1}$ produced soil contents considered average, while a double dose resulted in content values considered high for the annual crops.

The $\mathrm{Zn}$ content from the soil in this experiment was classified according to Raij et al. (1997), average content $\left(0.6-1.2 \mathrm{mg} \mathrm{dm}^{-3}\right)$ in treatments where the micronutrient was applied into the soil, the content was low $\left(0-0.5 \mathrm{mg} \mathrm{dm}^{-3}\right)$ in the control and in foliar application and seeds.

In the $\mathrm{Zn}$ content extracted by DTPA method there was a variation of 0.5 to $1.1 \mathrm{mg} \mathrm{dm}^{-3}$ and for Mehlich-1 extractor, 0.3 to $1.0 \mathrm{mg} \mathrm{dm}^{-3}$. However, Abreu and Raij (1996) in a study on the effect of the soil on the $\mathrm{Zn}$ extracted by different methods, have shown that Oxisol presents an amplitude of 0.9 to $1.2 \mathrm{mg} \mathrm{dm}^{-3}$ (DTPA) and 2.1 to $2.6 \mathrm{mg} \mathrm{dm}^{-3}$ (Mehlich-1). These differences can be explained by the content of the organic matter presented in the soils. In the citied work the content of the organic matter of the soil was approximately $37 \mathrm{~g}$ $\mathrm{dm}^{-3}$, while in the current study the content is $16 \mathrm{~g}$ $\mathrm{dm}^{-3}$, and, DTPA solution extracts, preferentially, the micronutrient is present in the organic matter.

The $\mathrm{Zn}$ application in soil compare to the one in the plant (foliar and seeds) (Table 1), stood out reaching higher contents of this nutrient in the soil $\left(1.1 \mathrm{mg} \mathrm{dm}^{-3}\right.$ - DTPA and $1.1 \mathrm{mg} \mathrm{dm}^{-3}-$ Mehlich-1 ), compared to the plant $\left(0.5\right.$ to $0.7 \mathrm{mg} \mathrm{dm}^{-3}-$ DTPA and $0.3 \mathrm{mg} \mathrm{dm}^{-3}-$ Mehlich-1), the same effect was obtained by Galrão (1996), who obtained the highest value of $2.4 \mathrm{mg} \mathrm{dm}^{-3}$ (the average from three crops), with the nutrient application in the soil.

It has been observed that the treatment where Zn was applied to the soil and incorporated provides an increased content of this micronutrient in soil for the two extractors, when compared to the banded application (Table 1), corroborating Galrão (1994) in the study of application methods of $\mathrm{Zn}$ in soil, in which applications of this nutrient, in incorporated manner, provided an elevated content in soil. Possibly this occurred by the usage of higher doses of $\mathrm{Zn}$ in the incorporated treatment, and also, a lower adsorption of this micronutrient in soil.

The application of $\mathrm{Zn}$ on the soil provided a rise in linear adjustment in the $\mathrm{Zn}$ content, banded manner $\left(\mathrm{y}=0.179 \mathrm{x}+0.55 ; \mathrm{R}^{2}=0.89^{*}\right)$ or incorporated $\left(\mathrm{y}=0.0274 \mathrm{x}+0.35 ; \mathrm{R}^{2}=0.99^{* *}\right)$, only by Mehlich-1 extractor, demonstrating increased sensibility and capacity of extracting the nutrient from the soil. Similar results have been verified by other authors, that the usage of acid solutions, as Mehlich-1 compare to DTPA, has a larger capacity of extracting $\mathrm{Zn}$ from soil, in studies involving two soils (Adônis et al., 2009), three soils (Consolini and Coutinho, 2004) and seven soils (Menezes et al., 2010). Other authors have mentioned that in general DTPA solution is better in relation to acid solutions in the evaluation availability of $\mathrm{Zn}$ in soils that have or not received the application of this element (Abreu and Raij, 1996). DTPA solution can be similar to the acid solutions due to the existence of a good correlation to the $\mathrm{Zn}$ content in the soil between the Mehlich-1 and DTPA methodology (Silva et al., 2009). In this way, Gonçalves Jr. et al. (2006) have observed that the complexant extractors, as DTPA, extract less Zn from the soil, having greater effectiveness in the acid soil.

These differences in the capacity of extraction highlight the problems in defining an adequate 


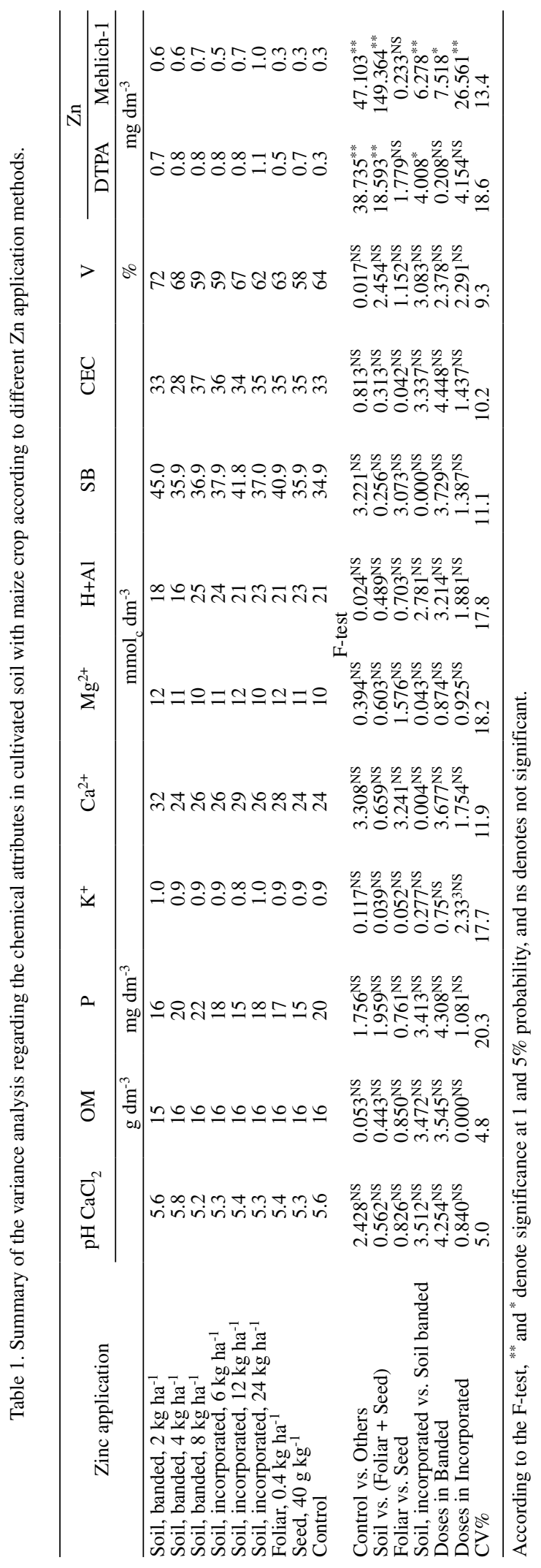

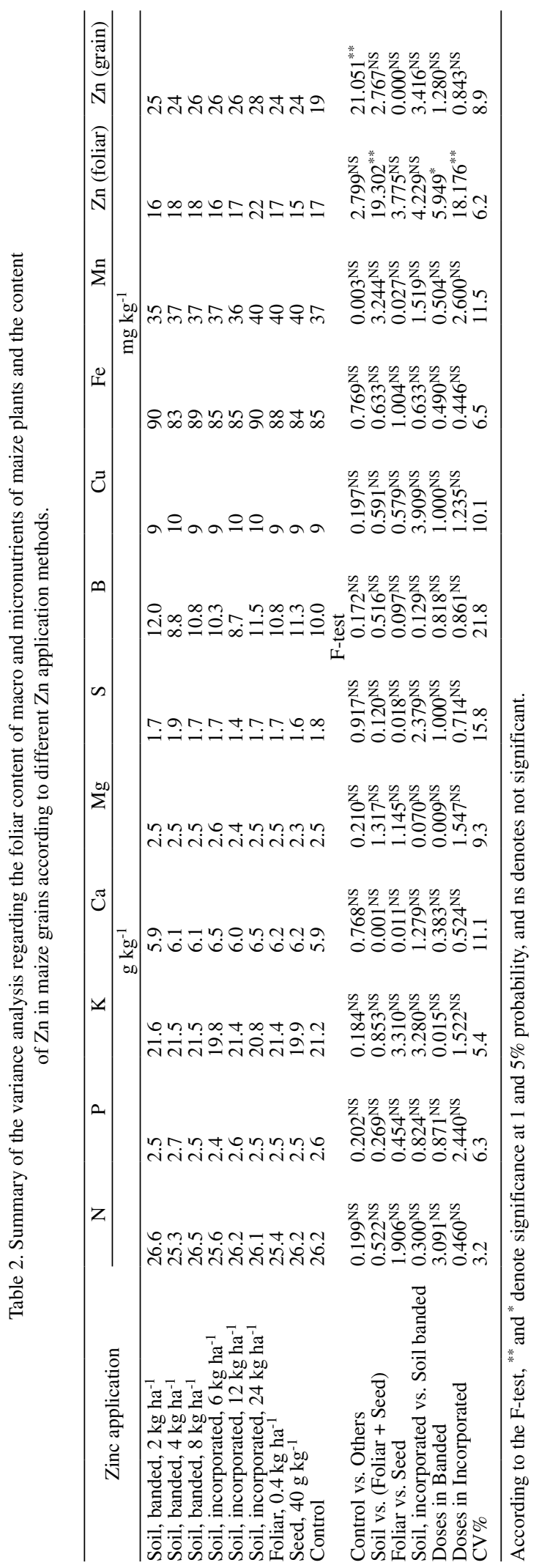


micronutrient extractor for the local conditions and distinct soil characteristics.

\section{Effects of the treatments on the content of the leaves of macro and micronutrients and Zn content in grains}

In all tested comparisons there were no differences in the foliar content of macro and micronutrients evaluated in the maize crop, except $\mathrm{Zn}$ (Table 2). For the $\mathrm{Zn}$ foliar content there was no differences between control and the other $\mathrm{Zn}$ treatments. However, there were differences in the following treatments: with $\mathrm{Zn}$ in soil, via foliar and seeds, and banded doses and incorporated doses (Table 2).

Decaro et al. (1983) in a study with doses and sources of $\mathrm{Zn}$ in maize crop, it was observed that the foliar content increased with the $\mathrm{Zn}$ doses applied to soil, corroborating current work. Although, the other studies with $\mathrm{Zn}$ application in soil, did not verify effects of this micronutrient in the foliar content of maize crop (Igue et al., 1962; Domingues et al., 2004).

The banded doses of applied $\mathrm{Zn}$ as well as the incorporated doses affected the foliar content of this micronutrient in maize plants (Table 2). It was noticed that this effect of the $\mathrm{Zn}$ applied in the banded manner promoted increment with quadratic adjustment $(\mathrm{P}<0.05)$ (Figure 1a) in the $\mathrm{Zn}$ foliar content, reaching the maximum dose of $6.0 \mathrm{~kg} \mathrm{ha}^{-1}$. On the other hand, $\mathrm{Zn}$ applied in the incorporated manner promoted increment with linear adjustment $(\mathrm{P}<0.01)$ (Figure 1b) in the $\mathrm{Zn}$ foliar content. These gains in the foliar content occurred due to the effect of $\mathrm{Zn}$ application in soil, that is, with the high availability of this micronutrient in soil, higher the uptake of the plants.

Even though $\mathrm{Zn}$ application has increased the foliar content of the said nutrient in plants, it was observed that the values were in the intervals of $15-100 \mathrm{mg} \mathrm{kg}^{-1}$ considered adequate by Cantarella and Raij (1997). Korndörfer et al. (1995) observed that $\mathrm{Zn}$ content in the maize leaf increased with doses of $\mathrm{Zn}$ applied to soil and the average content of $\mathrm{Zn}$ on the leaf varied from $13 \mathrm{mg} \mathrm{kg}^{-1}$ in the control to $23 \mathrm{mg} \mathrm{kg}^{-1}$ in the micronutrient treatment (4 $\mathrm{kg}$ of $\mathrm{Zn} \mathrm{ha}^{-1}$ ), and, in the present experiment, $\mathrm{Zn}$ content between 15 to $22 \mathrm{mg} \mathrm{kg}^{-1}$ was found.

As for the $\mathrm{Zn}$ content in grains, it was observed that $\mathrm{Zn}$ application promoted a higher content of
$\mathrm{Zn}$ (24 to $\left.28 \mathrm{mg} \mathrm{kg}^{-1}\right)$ compared to control (19 mg $\mathrm{kg}^{-1}$ ) (Table 2). Galrão (1994), in the study of the deficiency correction of $\mathrm{Zn}$ in maize, it was observed that the micronutrient content in grains varied little between the treatments ( $\mathrm{Zn}$ application methods) as in the present study. Ferreira et al. (2001) said that the $\mathrm{Zn}$ content in grains increased in $7 \%$ due to its application in the furrows, while in the present study this increase reached $32 \%$. In this sense, Kanwal et al. (2010) in a study with doses of Zn applied to soil in maize crop, verified a significant raise in the content of this micronutrient in maize grains (21.8 to $30.7 \mathrm{mg} \mathrm{kg}^{-1}$ ).

According to Welch (2002), the increase of the $\mathrm{Zn}$ application in soil significantly raises its concentration in parts of edible plants. Relatively higher content of $\mathrm{Zn}$ in maize grains is vital for human nutrition, that is, for the biofortification of basic food plantation (Graham et al., 1992). However, $\mathrm{Zn}$ in grains or seeds is a complex process that has a series of steps from its translocation by the roots to the shoots and, finally, phloem flush in the grain development (Welch, 1986).

By the Brazilian Food Composition Table, the content of $\mathrm{Zn}$ in green maize grains in natura is of $5 \mathrm{mg} \mathrm{kg}^{-1}$ (TACO, 2006), while in the present work the content of $\mathrm{Zn}$ in the grains obtained was of 19 to $28 \mathrm{mg} \mathrm{kg}^{-1}$. This fact is probably due to the differences of the grain development and distinct varieties.

\section{Effects of the treatments in the accumulation of $\mathrm{Zn}$ in the shoot and yield}

As to the dry material of the shoot, the $\mathrm{Zn}$ application independently of the manner, there was no difference when compared to the control (Table 3).

A confrontation of these results with field work using $\mathrm{Zn}$ in maize in literature (Galrão, 1994; Galrão, 1996; Gonçalves Júnior et al., 2007) was affected, because in these works the dry material of the plants were not evaluated, only the yield. However, there are some works with maize cultivated in pots (young plants), where the authors observed beneficial effects of $\mathrm{Zn}$ in the production of dry material of the shoot [Fageria (2000); Coutinho et al. (2001); Leite et al., 2003; Jamami et al., 2006; Prado et al.(2008)], and the other one observed, there was no effect of this micronutrient in the production of dry material in maize plants (Leal et al., 2007). 
Table 3. Summary of the variance analysis regarding the dry shoot material, grains per maize ear, 1000 grain mass and the maize crop yield according to different $\mathrm{Zn}$ application methods.

\begin{tabular}{|c|c|c|c|c|c|}
\hline \multirow[t]{2}{*}{ Zinc application } & $\begin{array}{l}\text { Dry matter on } \\
\text { the aerial part }\end{array}$ & $\begin{array}{c}\text { Accumulation } \\
\text { on the aerial } \\
\text { part }\end{array}$ & $\begin{array}{l}\text { Grains per } \\
\text { maize ear }\end{array}$ & $\begin{array}{l}1000 \text { grain } \\
\text { mass }\end{array}$ & Yield \\
\hline & $\mathrm{kg} \mathrm{ha}^{-1}$ & $\mathrm{~g} \mathrm{ha}^{-1}$ & & $\mathrm{~g}$ & $\mathrm{~kg} \mathrm{ha}^{-1}$ \\
\hline Soil, banded, $2 \mathrm{~kg} \mathrm{ha}^{-1}$ & 9974 & 101 & 474 & 355.1 & 10795 \\
\hline Soil, banded, $4 \mathrm{~kg} \mathrm{ha}^{-1}$ & 10238 & 111 & 431 & 357.8 & 9681 \\
\hline Soil, banded, $8 \mathrm{~kg} \mathrm{ha}^{-1}$ & 9723 & 121 & 470 & 376.4 & 10275 \\
\hline Soil, incorporated, $6 \mathrm{~kg} \mathrm{ha}^{-1}$ & 7588 & 101 & 460 & 356.2 & 11228 \\
\hline Soil, incorporated, $12 \mathrm{~kg} \mathrm{ha}^{-1}$ & 8149 & 115 & 453 & 353.3 & 10113 \\
\hline Soil, incorporated, $24 \mathrm{~kg} \mathrm{ha}^{-1}$ & 8314 & 145 & 473 & 350.0 & 11085 \\
\hline Foliar, $0.4 \mathrm{~kg} \mathrm{ha}^{-1}$ & 8107 & 104 & 443 & 346.0 & 9467 \\
\hline Seed, $40 \mathrm{~g} \mathrm{~kg}^{-1}$ & 8436 & 95 & 476 & 360.7 & 10126 \\
\hline Control & 8285 & 70 & $\begin{array}{c}452 \\
\text { F-test }\end{array}$ & 350.7 & 9965 \\
\hline Control vs. Others & $2.561^{\mathrm{NS}}$ & $50.844^{* *}$ & $0.239^{\mathrm{NS}}$ & $0.352^{\mathrm{NS}}$ & $0.198^{\mathrm{NS}}$ \\
\hline Soil vs. (Foliar + Seed $)$ & $8.070^{* *}$ & $19.899^{* *}$ & $0.004^{\mathrm{NS}}$ & $0.352^{\mathrm{NS}}$ & $8.193^{* *}$ \\
\hline Foliar vs. Seed & $0.550^{\mathrm{NS}}$ & $1.824^{\mathrm{NS}}$ & $2.220^{\mathrm{NS}}$ & $1.112^{\mathrm{NS}}$ & $2.205^{\mathrm{NS}}$ \\
\hline Soil, incorporated vs. Soil banded & $58.864^{* *}$ & $5.580^{*}$ & $0.082^{\mathrm{NS}}$ & $1.521^{\mathrm{NS}}$ & $4.756^{*}$ \\
\hline Doses in Banded & $0.584^{\mathrm{NS}}$ & $14.993^{* *}$ & $1.279^{\mathrm{NS}}$ & $1.151^{\mathrm{NS}}$ & $2.426^{\mathrm{NS}}$ \\
\hline Doses in Incorporated & $2.392^{\mathrm{NS}}$ & $22.186^{* *}$ & $0.650^{\mathrm{NS}}$ & $0.058^{\mathrm{NS}}$ & $3.368^{\mathrm{NS}}$ \\
\hline $\mathrm{CV} \%$ & 7.2 & 8.1 & 6.6 & 5.5 & 6.0 \\
\hline
\end{tabular}

According to the F-test, ${ }^{* *}$ and ${ }^{*}$ denote significance at 1 and $5 \%$ probability.

a)

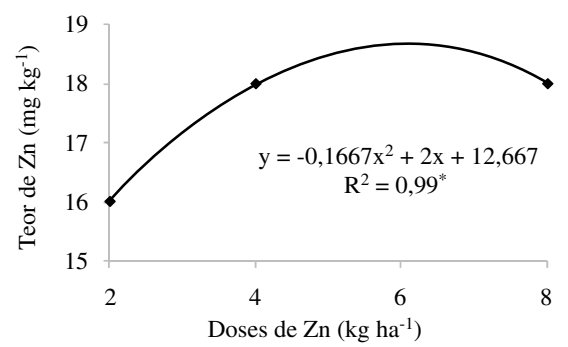

b)

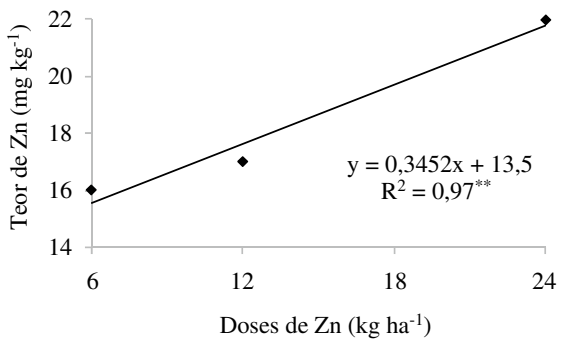

Figure 1. Contents of $\mathrm{Zn}$ in the maize plants leaves according to the banded application of $\mathrm{Zn}$ in soil.

When compared to the application in soil with the plant (seed and foliar), it was observed that added $\mathrm{Zn}$ to the soil induced a higher quantity of dry material in the maize plants (Table 3 ).

Studying the $\mathrm{Zn}$ banded application and the incorporated one, it was noticed that the $\mathrm{Zn}$ banded application induced a higher quantity of dry material when compared to the incorporated micronutrient application. Nonetheless, when studying the doses in the banded and incorporated treatment of the micronutrient, no differences were found between the treatments (Table 3).

Observing the comparison between the control $v s$ the other treatments, it was seen that the $\mathrm{Zn}$ application induced a higher accumulation of $\mathrm{Zn}$ in the shoot compared to the control (Table 3). In spite of Prado et al. (2008) studying the $\mathrm{Zn}$ application manners in maize cv. BRS 1001, in a greenhouse, it was verified that differences between the treatments and control, with the exception of the banded and seed treatment, in the accumulation of $\mathrm{Zn}$ in the shoots.

Even so comparing the application in the soil with the plant application, it was noted that the application in the soil did not cause a higher accumulation of this micronutrient in the plants. Observing the comparison of the application in the soil, the banded and incorporated method, 
differences were established, in which the $\mathrm{Zn}$ application by incorporation in the soil provided higher accumulation of micronutrient (Table 3 ).

It was noticed that the banded $\mathrm{Zn}$ application in soil promoted increment with quadratic adjustment $(\mathrm{P}<0.01)$ (Figura 2a), and, in the incorporated application with the linear adjustment $(\mathrm{P}<0.01)$ (Figura $2 \mathrm{~b}$ ) in the accumulation of $\mathrm{Zn}$ in the shoot. Similar results were obtained by other authors, whereas the $\mathrm{Zn}$ application incremented the accumulation of this nutrient in the leaves (Leite et al., 2009) and in the maize crop shoot (Coutinho et al., 2001).

As to the maize crop grains, it can be observed in Table 4, that there were no differences between the treatments for the number of grains per maize ear and the 1.000 grain mass, corroborating Galrão (1994), in experiment with correction methods of $\mathrm{Zn}$ deficiency in maize in the field, where the numbers of grains in the ear did not present significant variations between treatments ( $\mathrm{Zn}$ application in soil, seed and leaves). Decaro et al. (1983) in study with doses $\left(5,10\right.$ and $\left.15 \mathrm{~kg} \mathrm{ha}^{-1}\right)$ and $\mathrm{Zn}$ source in the maize crop, differences were not found as to the weight of a hundred seeds. Ferreira et al. (2001) in field experiment with maize fertilized with $\mathrm{Zn}$, it was reported that the weight of a thousand grains was not influenced by the $\mathrm{Zn}$ application. Whilst Ávila et al. (2006), in micronutrients application study in maize seeds in Ultisol, it was observed that the seed treatment did not affect the number of seeds on the ear.

As the yield of the maize plants, it was noticed that there were no differences when compared to the $\mathrm{Zn}$ application and the control (Table 3). The absence of $\mathrm{Zn}$ treatment effects, in the maize crop yield can be explained by the fact that there were no differences in the nutritional state of the plants (Table 2) and in the production of dry material of the shoot (Table 3). Besides that, the average yield of this experiment (10.304 kg ha $\left.{ }^{-1}\right)$ was higher than the average Brazilian production, harvest crop 2012/2013 (4.972 $\mathrm{kg} \mathrm{ha}^{-1}$ ) (CONAB, 2013).

The absence of $\mathrm{Zn}$ effect in the maize crop yield corroborates Jamami et al. (2006), in study of how to apply $\mathrm{Zn}$ in maize crop, it was verified that the application of this micronutrient in the soil has not increased the production. As Korndörfer (1995) who tested manners of adding Zn to NPK formula on maize crop, it was noticed that there was no effect on the maize production, independently of the dose or the manner used. However, Galrão (1994) in a study of methods of applying $\mathrm{Zn}$ in maize, in the field, it was observed that there was crop yield increase due to the treatments ( $\mathrm{Zn}$ application in the soil, seeds and leaves), except the treatment with $0.4 \mathrm{~kg} \mathrm{ha}^{-1}$ of $\mathrm{Zn}$ in the furrows. In the same way, other studies have indicated that the $\mathrm{Zn}$ banded application or incorporated using $5 \mathrm{~kg} \mathrm{ha}^{-1} \mathrm{Zn}$ (Domingues et al., 2004) and higher doses (5 to $15 \mathrm{~kg} \mathrm{ha}^{-1}$ ) (Decaro et al., 1983), provided significant increases in the maize production.

When compared to the application in soil vs application on the plant (foliar and seeds), it was seen that the $\mathrm{Zn}$ application in soil promoted a higher maize plant yield. Nevertheless, Igue et al. (1962) studying the influence of $\mathrm{Zn}$ in the maize production, in the field, differences were not observed in the production when $\mathrm{Zn}$ was applied to the soil and foliar. However, Ávila et al. (2006) in a field study where micronutrients were applied to the maize seed in a Ultisol clay texture, the treated seeds did not present satisfactory results in increasing the seed yield in five evaluated hybrids. Yet, Potarzycki a)

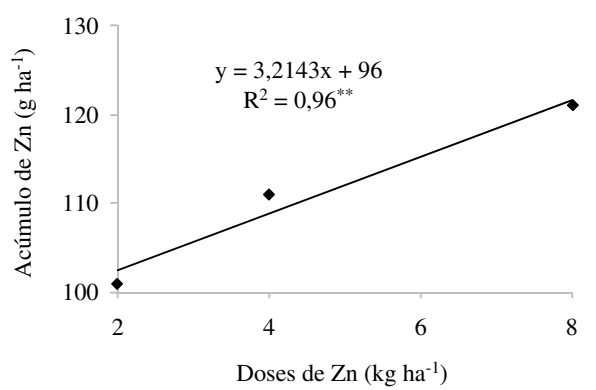

b)

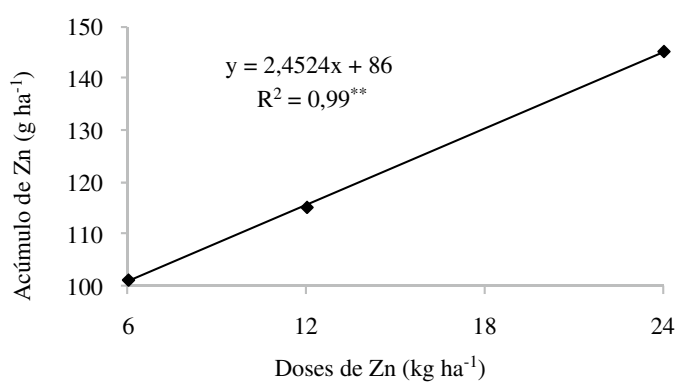

Figure 2. the accumulation of $\mathrm{Zn}$ in the maize plant shoot according to the $\mathrm{Zn}$ application in the soil by the banded manner (a) and incorporated (b). 
and Grzebisz (2006) in the study with Zn applied via foliar (oxisulphate) in maize in Alfisol in three consecutives years, there was an increase in grains (three year average) with doses of 1.0 to $1.5 \mathrm{~kg}$ of $\mathrm{Zn} \mathrm{ha}^{-1}$, compared to the treatment that had not received micronutrient.

The applied Zn by soil incorporation resulted in a higher maize yield when compared to the banded application (Table 3). This occurred due to the incorporated application having received a higher dose of $\mathrm{Zn}$, with greater availability of this micronutrient in soil (Table 1), as well as this nutrient in the leaves (Table 2) and consequently in the yield. However, Souza et al. (1998) in experiment with doses of applied $\mathrm{Zn}$ in furrows in Oxisol $\mathrm{Zn}$ : $0.39 \mathrm{mg} \mathrm{dm}^{-3}$ ), it was found that the addition of $\mathrm{Zn}$ promoted an increase in the maize production and in the concentration of this micronutrient in leaves, even though there were no advantages in applying superior doses of $5 \mathrm{~kg} \mathrm{ha}^{-1}$ of $\mathrm{Zn}$. Notwithstanding, Ferreira et al. (2001) in the field study of maize crop fertilized with $\mathrm{Zn}$, it was reported that there was no increase in the production with the application of $3 \mathrm{~kg} \mathrm{ha}^{-1}$ of $\mathrm{Zn}$ in the furrow. Though, Kanwal et al. (2010) in study with $\mathrm{Zn}$ doses applied to soil, it was verified the maximum yield of the cultivated hydride maize (FHY-421) when applying $18 \mathrm{~kg} \mathrm{ha}^{-1}$ of $\mathrm{Zn}$, while the used variety (Golden) reached the maximum yield of $9 \mathrm{~kg} \mathrm{ha}^{-1}$ of $\mathrm{Zn}$.

As there were no significant differences of the treatment doses incorporated to the soil (Table 4), hence the lower dose $\left(6 \mathrm{~kg} \mathrm{ha}^{-1}\right)$, could represent an economy in micronutrient.

\section{Conclusions}

1. The $\mathrm{Zn}$ application independently of the manner, provided a higher content of this micronutrient in the soil and higher accumulation in the shoot which reflected in the maize grain, however, it did not affected the nutritional state and the maize yield.

2. The $\mathrm{Zn}$ application in the soil promoted a higher $\mathrm{Zn}$ uptake by the plants and maize yield, compared to the application of this micronutrient on the plant via seeds or foliar. In the soil, incorporated manner, in the dose of $6 \mathrm{~kg} \mathrm{ha}^{-1}$ of $\mathrm{Zn}$, the banded application stood out.

\section{Literature Cited}

Abreu, C.A.; Raij, B. Van.

1996. Efeito da reação do solo no zinco extraído pelas soluções de DTPA e Mehlich-1. Bragantia 55: 357-363.

Abreu, C.A.; Ferreira, M.E.; Borkert, C.M.

2001. Disponibilidade e avaliação de elementos catiônicos: zinco e cobre. In: Ferreira, M.E.; Cruz, M.C.P.; Raij, B. van; Abreu C.A. Micronutrientes e elementos tóxicos na agricultura: CNPq/Fapesp/Potafos. Jaboticabal. pp. 125-150.

Adônis, M.; Wenceslau, G.T.; Gilvan, C.M.

2009. Extratores e disponibilidade de micronutrientes em Terra Preta de Índio da Amazônia Central. Ciencia del Suelo 27: 127-134.

Ávila, M.R.; Braccini, A.L.; Scapim, C.A.; Martorelli, D.T.; Albrecht, L.P.; Faciolli, F.S.

2006. Qualidade fisiológica e produtividade das sementes de milho tratadas com micronutrientes e cultivadas no período de safrinha. Acta Scientiarum Agronomy 28: 535-543

Bowen, H.J.M.

1979. Environmental Chemistry of the Elements New York: Academic Press. 273 pp.

Cantarella, H.; Raij, B. Van; Camargo, C.E.O. Cereais. In: Raij,

B. Van; Cantarella, H.; Quaggio, J.A.; Furlani, A.M.C.

1997. Ed(s). Recomendações de adubação e calagem para o estado de São Paulo: Instituto Agronômico. Campinas. 2 ed. rev. p. 47 (Boletim técnico, 100).

Conab

2013. Acompanhamento da safra brasileira: grãos, oitavo levantamento, Companhia Nacional de Desenvolvimento. Brasília, DF. Maio de 2013. 30 pp.
Consolini, F.; Coutinho, E.L.M.

2004. Efeito da aplicação de $\mathrm{Zn}$ e do $\mathrm{pH}$ do solo na disponibilidade do micronutriente. Acta Scientiarum Agronomy 26: 7-12.

Coutinho, E.L.M.; Natale, W.; Consolini, F.; Silva, A.R.; Franco, H.C.J.

2001. Resposta do milho doce à adubação com zinco. Revista Ecossistema 26: 181-186.

Decaro, S.T.; Vitti, G.C.; Fornasieri Filho, D.; Melo, W.J. 1983. Efeitos de doses e fontes de zinco na cultura do milho (Zea mays L.). Revista de Agricultura 58: 25-36.

Domingues, M.R.; Buzetti, S.; Alves, M.C.; Sassaki, N.

2004. Doses de enxofre e de zinco na cultura do milho em dois sistemas de cultivo na recuperação de uma pastagem degradada. Científica 32: 147-151.

Embrapa

2006. Centro Nacional e Pesquisa em Solos. Sistema Brasileiro de Classificação de Solos. Brasilia: Embrapa-SPI; Rio de Janeiro: Embrapa-Solos. 306 pp.

Fageria, N.K.

2000. Níveis adequados e tóxicos de zinco na produção de arroz, feijão, milho, soja e trigo em solo de cerrado. Revista Brasileira de Engenharia Agrícola e Ambiental 4: 390-395.

Fageria, N.K.

2001. Avaliação de genótipos de arroz na eficiência de uso de zinco. Scientia agricola 58: 623-626.

Fageria, N.K.; Baligar, V.C.; Clark, R.B.

2002. Micronutrients in crop production. Advances in Agronomy 77: $185-268$. 
Ferreira, A.C.B.; Araújo, G.A.A.; Pereira, P.R.G.; Cardoso, A.A. 2001. Características agronômicas e nutricionais do milho adubado com nitrogênio, molibdênio e zinco. Scientia Agricola 58: 131-138.

Galrão, E.Z.

1994. Métodos de correção da deficiência de zinco para o cultivo do milho num Latossolo Vermelho-Escuro argiloso sob cerrado. Revista Brasileira de Ciência do Solo 18: 229-233.

Galrão, E.Z.

1996. Métodos de aplicação de zinco e avaliação de sua disponibilidade para o milho num Latossolo VermelhoEscuro, argiloso, fase cerrado. Revista Brasileira de Ciência do Solo 20: 283-289.

Gonçalves Jr, A.C.; Prestes, A.L.; Trautmann, R.R.; Santos, A.L.; Andreotti, M.

2006. Avaliação de extratores e fitodisponibilidade de zinco para cultura do milho em Latossolo Vermelho eutroférrico. Acta Scientiarum Agronomy 28: 7-12.

Gonçalves Jr, A.C.; Trautmann, R.R.; Marengoni, N.G.; Ribeiro, O.L.; Santos, A.L.

2007. Produtividade do milho em resposta a adubação com NPK e Zn em Argissolo Vermelho-Amarelo Eutrófico e Latossolo Vermelho Eutroférrico. Ciência e Agrotecnologia 31: 1231-1236.

Graham, R.D.; Ascher, J.S.; Hynes, S.C.

1992. Selecting zinc-efficient varieties for soils of low zinc status. Plant Soil 146: 241-250.

Igue, K.; Blanco, H.G.; Andrade Sobrinho, J.

1962. Influência do zinco na produção do milho. Bragantia 21: 263-269.

Jamami, N.; Büll, L.T.; Corrêa, J.C.; Rodrigues, J.D. 2006. Resposta da cultura do milho (Zea mays L.) à aplicação de boro e de zinco no solo. Acta Scientiarum Agronomy 28: 99-105.

Kanwal, S.; Rahmatullah, A.M.R.; Rashid Ahmad, R. 2010. Zinc partitioning in maize grain after soil fertilization with zinc sulfate. International Journal of Agriculture \& Biology 12: 299-302.

Korndörfer, G.H.; Alcântara, C.B.; Horowitz, N.; Lana, R.M.Q. 1995. Formas de adição de zinco a um formulado NPK e seu efeito sobre a produção de milho. Scientia Agricola 52: $555-560$.

Leal, R.M.

2007. Efeito da aplicação de zinco em sementes sobre a nutrição e a produção de massa seca de plantas de milho. Acta Scientiarum Agronomy 29: 491-496.

Leite, U.T.; Aquino, B.F.; Rocha, R.N.C.; Silva, J.

2003. Níveis críticos de boro, cobre, manganês e zinco em milho. Bioscience Journal 19: 115-125.

Lopes, A.S.

1983. Solos sob cerrado: características propriedades e manejo. Piracicaba: Potafós, 162 p.

Lucas, R.E.; Knezek, B.D.

1972. Climatic and soil conditions promoting micronutrient deficiencies in plants. In: Mortvedt, J.J.; Giordano, P.M.; Lindsay, W.L. (Ed.). Micronutrients in agriculture. Madison: Soil Science Society of America, p. 265-288.

Malavolta, E.

1980. Elementos de nutrição de plantas. São Paulo: Agronômica Ceres, $251 \mathrm{p}$.

Malavolta, E.

2006. Manual de nutrição mineral de plantas. São Paulo: Ceres, $638 \mathrm{p}$.
Marschner, $\mathrm{H}$.

1995. Mineral nutrition of higher plants. 2nd ed. London: Academic Press, 889 p.

Melarato, $\mathrm{M}$.

2000. Micronutrientes no sistema plantio direto. In: Simpósio Sobre Fertilidade do Solo e Nutrição de Plantas no Sistema Plantio Direto, Ponta Grossa: Associação de Engenheiros Agrônomos de Campos Gerais, pp. 161-174.

Menezes, A.A.; Dias, L.E.; Neves, J.C.L.; Silva, J.V.O.

2010. Disponibilidade de zinco para milho pelos extratores Mehlich-1, Mehlich-3 e DTPA em solos de minas gerais, na presença e ausência de calagem. Revista Brasileira de Ciência do Solo 34: 417-424.

Nelson, W.L.; Mehlich, A.

1953. The Development, evaluation, and use of soil tests for phosphorus availability. Agronomy 4: 153-188.

Orioli Júnior, V.; Prado, R.M.; Leonel, C.L.; Cazetta, D.A.; Silveira, C.M.; Queiroz, R.J.B.; Bastos, J.C.H.A.G.

2008. Modos de aplicação de zinco na nutrição e na produção de massa seca de plantas de trigo. Revista de la Ciencia del Suelo y Nutrición Vegetal 8: 28-36.

Potarzycki, J.; Grzebisz, W.

2009. Effect of zinc foliar application on grain yield of maize and its yielding components. Plant, Soil and Environment 55: 519-527.

Prado, R.M.; Romualdo, L.M.; Rozane, D.E.; Vidal, A.A.;

Marcelo, A.V.

2008. Modos de aplicação de zinco na nutrição e na produção de matéria seca do milho BRS 1001. Bioscience Journal 24: 67-74.

Raij, B, Van.; Cantarella, H. Milho para grãos e silagem. In: Raij,

B. Van.; Cantarella, H.; Quaggio, J.A.; Furlani, A.M.C.

1997. Ed(s). Recomendações de adubação e calagem para o estado de São Paulo Instituto Agronômico. Campinas. 2 ed. rev. pp. 45-47 (Boletim técnico, 100).

Raij, B. Van.; Andrade, J.C.; Cantarella, H.; Quaggio, J.A.

2001. (Ed.). Análise química para avaliação da fertilidade do solo: Instituto Agronômico. Campinas. 285 pp.

Romualdo, L.M.

2008. Modos de aplicação de zinco no crescimento inicial de plantas de milho e de sorgo em casa de vegetação. 43 pp. Dissertação de Mestrado, Faculdade de Ciências Agrárias e Veterinárias-Universidade Estadual Paulista. Jaboticabal.

Silva, M.A.G.; Muniz, A.S.; Noda, A.Y.; Marchetti, M.E.; Mata,

J.D.V.; Lourente, E.R.P.

2009. Metodologias e eficiência de extratores para zinco, cobre, ferro e manganês. Acta Scientiarum Agronomy 31: 537-545.

Souza, E.C.A.; Coutinho, E.L.M.; Natale, W.; Barbosa, J.C. 1998. Respostas do milho à adubação com fósforo e zinco. Pesquisa Agropecuária Brasileira 33: 575-582.

Taco

2006. Tabela Brasileira de Composição de Alimento: NEPA/ UNICAMP. Campinas, SP. Versão 2. 2 ed. 113 pp.

Welch, R.M.

1986. Effects of nutrient deficiencies on seed production and quality. Advances in Plant Nutrition 2: 205-247.

Welch, R.M.

2002. The impact of mineral nutrients in food crops on global human health. Plant Soil 247: 83-90. 
